\title{
IMMUNOLOGIC INVESTIGATIONS IN DIAGNOSTICS OF ACUTE CEREBROVASCULAR DISEASE
}

\author{
Kasimova N.S., Prof. Madjidova E.N.* \\ Tashkent Medical Institute of Pediatrics, Tashkent, Uzbekistan
}

Abstract. Based on the literature data it can be argued that lateralization lesion determines the clinical and immunological parameters in patients with acute cerebral accidence. While there is a close relationship with the immune mechanisms of factors that play a role in the pathogenesis of cerebral circulation. It should be noted that further detailed study of immunopathological phenomena in early age children help outline new diagnostic and pathogenetic based pharmacotherapy of acute cerebrovascular events.

Key words: acute cerebrovascular diseases, stroke, immune mechanisms.

$\overline{\mathbf{I}}$ ncidence of acute cerebrovascular disease (ACVD) in pediatric population varies based on literature review, ranging between 2-7 cases per 100000 population per year. Available international medical data and medical statistics reveal that incidence of stroke among newborns during first month of their lives is comparable to that of adults at the age of 50-55; average incidence rate of pediatric stroke (from 1 month to 14 years) is about 7-8 cases per 100000 population per year [7, 13, 17, 20].

Further study of the current pediatric disorder is mandated by high mortality and disability rates, as well as low awareness of medical professionals with peculiarities of the disease in pediatric population, which is often accompanied by difficulties in diagnostics of strokes, especially at the stage of primary care $[13,21,23]$.

High diversity of etiologic factors resulting in vascular events in patients of young ages complicates developing management algorithms, as well as primary and secondary prevention system [19].

Significant decline in negative outcomes of ACVD both for patients and society is only possibly via deep understanding of causes and pathogenesis of this disease [16, 22]. Immunopathologic changes have been assumed to play a significant role in development of ACVD recently [6, 12, 14, 18].

An important progress has been made in understanding pathologic basics of ACVD in recent years. Research on cell and molecular level has shown that, cerebral ischemia not only results in morphologic changes in brain tissue, but it also triggers a sophisticated complex of secondary factors of brain damage, such as free radical-calcium pathway of neuronal damage and disorders in genetic mechanisms $[2,14]$.
Clearly, regression of various manifestations of neurologic deficit and psychological disorders in cerebrovascular pathology is highly dependent on complex interactions on morphologic, functional, and psychological levels.

Participation of immune mechanisms has been noted in pathogenesis of stroke (autoimmune aggression, apoptosis, focal inflammatory reactions with participation of cytokines). A close relationship exists between the level of immunologic disorders and severity of stroke, recovery, and disease outcome [10].

Extensive research studies in this field have served to deepen understandings regarding participation of immune response, inflammatory reactions, and genetic and molecular pathways of apoptosis in pathogenesis of ischemic stroke [9, 10, 12, 22].

A number of studies have demonstrated that central nervous system disorders with involvement of neuro-immuno-regulatory apparatus are key factors in development of immune-deficit conditions. Here, neuro-immuno-regulatory changes may occur both on inter-system level and on the level of reception of regulatory factors by immunocompetent cells [5].

Role of Matrix Methalloproteinase-9 (MMP9) has been studied in development of complications following thrombolytic therapy [14]. Research has been conducted demonstrating evidence for role of polymorphism of various genes, including apoptosis-inducing Fas gene in formation of cerebral ischemic sites [11].

Secondary damage pathways are activated as an outcome of pathobio-chemical processes, among which higher importance is given to focal inflammation reactions and autoimmune aggression $[3,5,12]$.

*e-mail: madjidova1@yandex.ru 
Recent research has established novel approach in understanding brain tissue damage during acute cerebral ischemia, determining key mechanisms of progression of reversible hemodynamic, cell, and molecular changes into brain infarction, a sustainable focal morphologic defect $[1,6]$. It has been determined, that immunologic mechanisms play an important role in pathogenesis of ischemic stroke in acute period, along with glutamate-calcium cascade and excitotoxicity.

Simultaneously, new evidence is being accumulated regarding role of congenital immunity in formation of response by cerebral tissue to ischemia. Thus, participation of congenital immune receptors named Toll-like receptors 4 (TLR4) in development of experimental cerebral infarction has been demonstrated [18]. Role of various apoptosis mediators, including Fas-ligand (FasL) in pathogenesis of ischemic stroke, potential neuroprotective action of heat shock proteins 70 (HSP70) [22], as well as role of methalloproteinases in development of cerebral infarction are being actively investigated.

Previous research data has revealed, that immune system is activated during first hours following stroke, which is evidenced by high serum and CSF levels of anti-DNA antibodies, main protein myelin, and collagen [14].

Absence of decline in antibody levels down to norm range by the end of acute period may predict significant intensity of destructive processes in site of ischemia. Degree of increase in organ-specific and non-organ-specific antibodies both in first days and during the whole acute period has a predicting value, as higher concentrations correlate with more severe clinical course and outcome of stroke.

Immunologic studies conducted with enrollment of acute circulatory disorder patients have revealed suppression of T-cell-related processes in this cohort $[15 ; 19 ; 21 ; 22]$. In addition, decline in activity level of NK cells has been observed [2;14]. Activation of humoral immunity (increase in number of B-lymphocytes, CIC (circulating immune complexes), and imunoglobulins) has been reported, as well $[4,9,10]$.

Several authors have determined relationship between degree of immune disorders, recovery level of neurologic functions, and overall disease outcome.

Identified deficit on T-cell level of immune system may be caused by redistribution and fixation of lymphocytes in lymphoid organs and delay in precursor cell release from bone marrow due to excessive stress condition such as stroke [20]. Decline in level of T-cells, their main subpopulations, and NK cells in peripheral blood may be explained with their migration through damaged hematoencephalic barrier into damage site of central nervous system and their participation in local immune response here.

A number of authors believe [8], that activation of humoral immunity is way of expression of autoimmune response to release of neuroantigens into peripheral blood and production of neuro-antibodies.

Thus, neuro-immune regulation disorders may arise both on inter-system level and on the level of reception of regulatory factors by immunocompetent cells.

Currently, several authors have shown that a disbalance in cytokine status with deficiency in protective anti-inflammatory cytokine and trophic factor status [4, 14], degree of which correlates with severity and clinical outcome of stroke takes place upon formation of cerebral infarction; a significant role of auto-immune processes in brain ischemia has been determined [5].

Complicated dynamics of interleukins IL-1a and IL-10 with development of cytokine imbalance is observed in acute period of stroke. Ratio of pro- and anti-inflammatory cytokines depends on time passed since disease onset and magnitude of ischemic damage: the higher is the level of pro-inflammatory cytokines and the lower is the level of anti-inflammatory cytokines, the more severe will be the clinical course [22].

Significant decline in pro-inflammatory cytokines by the end of acute period of stroke compared to initial days of the disease may predict high probability of favorable long-term outcomes [5].

Along with above-said, titers of cytokines such as IL-4, IL-8, IFN- , and TNF- also increased in peripheral blood, which is due to their increased production by activated microglial and immune cells during stroke. TNF- and IL-8 already produced in first days participate in non-specific protective reactions, regulating all stages of inflammatory process at the site of lesion [10].

According to some authors, level of IL-4 also increases along with other anti-inflammatory cytokines, whereas [22] another group of authors 
report a decrease in level of anti-inflammatory cytokines during first hours since onset of stroke [10].

As to INF-, which plays a role both as proand anti-inflammatory cytokine, its most significant effect is due to participation of this cytokine in regulation of T-cell immunity [22].

Development of immune-deficient status in multiple pathologic conditions has recently been related to higher level of apoptosis of immune competent cells. Probably, determined increase in level of TNF- in peripheral blood by a number of scientists induces TNF- -based pathway of immune cell apoptosis [12].

IL-2 deficiency also plays a role in aggravation of apoptotic destruction of immune-competent cells, which is reported in works of several authors [3, 22].

Thus, despite extensive research data available, only individual reports are provided in literature regarding clinical research studies targeting the role of immunologic process and local inflammation phenomenon in pathogenesis of acute cerebral circulatory disorders on acute stage, especially in children of young ages.

In the meanwhile, available date shows that

\section{REFERENCES}

1. Виленский Б. С. Осложнения инсульта: профилактика и лечение. Санкт - Петербург: изд-во "Фолиант", 2000. 128 с. 2. Гусев Е. И. Проблема инсульта в России //Журн. неврологии и психиатрии им. С.С. Корсакова (приложение "Инсульт"). М., 2003. - №9. - С.3-7.

3. Дусчанов Ш. Б., Рахимбаева Г. С. Иммунологическая и клиническая эффективность применения инстинона при острых нарушениях мозгового кровообращения //Аллергия, астма и клиническая иммунология. 2003. - T. 7. - №1. - С.13-16.

4. Евтушенко С.К., Яновская Н.В., Евтушенко О.С., Лисовский Е.В. Цитиколин как эффективный нейропротектор в лечении и реабилитации детей первого года жизни с органическими поражениями ЦНС // Медицинская неврология. - 2007. - №3. - С. 45-49.

5. Жданов Г.Н. Клинические и иммунологические аспекты в дифференциальной диагностике, лечении и прогнозировании ишемического инсульта. Дис. ... док. мед. наук. - М., 2007. - 317 с.

6. Земсков А. М., Земсков М. А., Золодедов В.И., Притулина Ю. Г., Болотских В. И. Типовые реакции иммунной системы при различных патологических процессах //Журн. теоретической и практической медицины. - 2004. - Т. 2. - №1. - С. 6-12. 7. Зыков В.П., Комарова И.Б., Чучин М.Ю. Диагностика и лечение инсульта у детей. Учебное пособие. Москва. 2008. - 61с.

8. Инсульт в молодом возрасте: Методические рекомендации. М. М. Одинак и др. - М.: ГВКГ им. Н. Н. both immunologic abnormalities and prevailing type of immune-deficiency during stroke have been insufficiently studied, which is especially true for children of young ages.

No data is available regarding level of cytokines in progression of pediatric stroke. Role of pro- and anti-inflammatory cytokines in cerebrovascular disorders remains uninvestigated.

Immunologic monitoring during initial hours of pediatric stroke has a great significance in clinical practice, as this allows for better determination of severity and predicting further course and outcome of the disease.

In the world of novel diagnostic technologies, exploration of immunologic criteria in differential diagnosis of ischemic and hemorrhagic strokes presents a significant scientific and practical interest. Contact-type intercellular interaction pathways in formation of brain infarction have not been established. No effective immune-modulating therapy has been developed to decrease local inflammatory reaction and autoimmune aggression, which in its turn could decrease mortality and disability, as well as increase quality of life in children of young ages.

Бурденко, 2001. - 63 с.

9. Крыжановский Г.Н., Магаева С.В, Макаров С.В., Сепиашвили Р.И. Нейроиммунопатология. Руководство. - М.: изд-во НИИ общей патологии и патофизиологии, 2003. - $438 \mathrm{c.}$

10. Медведева С.Л., Герасимова М.М. Клинико-иммунологические аспекты церебрального инсульта //Журн. неврологии и психиатрии им. С.С. Корсакова (приложение "Инсульт"). - 2003. - №9. - С.134.

11. Принципы диагностики и лечения больных с острыми нарушениями мозгового кровообращения. Методические рекомендации. /Н. В. Верещагин и др. Москва, 2000. - 28 с.

12. Ребенко Н.М. Клинико-иммунологические особенности у больных в остром периоде ишемического инсульта. Автореф. дисс. ... канд. мед. наук. - Новосибирск., 2004. - С. 24.

13. Садыкова Г.К., Кадыровой 3.А. Клинико-неврологические аспекты нарушений мозгового кровообращения у новорожденных и пути ранней реабилитации его последствий: Методические рекомендации. - Ташкент, 2011. - $31 \mathrm{c}$.

14. Страченко А.А. Клиническая нейроиммунология хирургических заболеваний головного мозга.. В 2-х частях. - Санкт-Петербургское медицинское изд-во, 2001. - Ч.1. - $328 \mathrm{c}$.

15. Федин А.И., Румянцева С.А. Избранные вопросы базисной интенсивной терапии нарушений мозгового 
кровообращения. Методические указания. - М.: изд-во "Интермедика", 2002. - 256 с.

16. Фейгина А.А. Клинические и нейроиммунологические аспекты эпилептических приступов постинсультного. Дис. ... канд.мед.наук. - Москва, 2008. - 125 с.

17. Шамансуров Ш.Ш., Студеникин В.М. Неврология раннего детства. - Ташкент, 2010. - 616с.

18. Brasseur-Daudruy M., Bordarier C., Cellier C., Eurin D. et al. Cerebral infarction in full-term newborns: MR imaging features // J Radiologie. - 2008. - Vol 89. - p. 1085-1093

19. Cnossen M.H., van Ommen C.H., Appel I.M. Etiology and treatment of perinotal stroke; a role for prothrombotic coagulation factors? // Seminars in Fetal and Neonatal Medicine. - 2009. - 14 (5). - p. 311-317.

20. Dudink J., Mercuri E., Al-Nakib L., Govaert P.
Evolution of unilateral perinotal arterial ischemic stroke on conventional and diffusion-weighted MR imaging. // Neuroradiol. - 2009. - 30. - p. 998-1004.

21. Golomb M.R, Garg B.P, Edwards-Brown M., Williams L.S. Very early arterial ischaemic stroke in premature infants // Pediatr Neurol. - 2008. - 38. - p. 329-34. 22. Kim H. M., Shin H.Y., Jeong H.J., An H.J., Kim N.S., Chae H.J., Kim H.R., Song H.J., Kim K.Y., Baek S.H., Cho K.H., Moon B.S., Lee Y.M. Reduced IL-2 but elevated IL-4, IL-6, and $\mathrm{IgE}$ serum levels in patients with cerebral infarction during the acute stage. //J Mol Neurosci. - 2000. - Vol 14(3). - P. 191-6.

23. Simchen M.J., Goldstein G., Lubetsky A. et al. Factor v Leiden and antiphospholipid antibodies in either mothers or infants increase the risk for perinatal arterial ischemic stroke // Stroke. - 2009. - 40. - p. 65-69.

\title{
РЕЗЮМЕ
}

\section{ИММУНОЛОГИЧЕСКИЕ ИССЛЕДОВАНИЯ В ДИАГНОСТИКЕ ОСТРЫХ НАРУШЕНИЙ МОЗГОВОГО КРОВООБРАЩЕНИЯ}

\author{
Касимова Н.С., Проф. Маджидова Е.Н. \\ Таикентский педиатрический медицинский институт
}

На основании литературных данных можно утверждать, что латерализация поражения определяет клинические и иммунологические параметры у больных с острым нарушением мозгового поражения. При этом отмечается тесная взаимосвязь иммунных механизмов с факторами, играющими определенную роль в патогенезе нарушений мозгового кровообращения. Необходимо отметить, что дальнейшее детальное изучение иммунопатологических феноменов у детей раннего возраста позволит наметить новые возможности диагностики и патогенетически обоснованной фармакотерапии острых нарушений мозгового кровообращения.

Ключевые слова: острые нарушения мозгового кровообращения, инсульт, иммунные механизмы.

\section{XÜLASə}

\section{BEYIN QAN DÖVRANININ KOSKIN POZULMALARININ DIAQNOSTIKASINDA İMMUNOLOJI TODQIQATLAR}

\author{
Kasimova N.S., Prof. Madjidova E.N. \\ Daşkənd pediatrik tibb institutu, Daşkənd, Özbəkistan
}

Odəbiyyatlardakı məlumatlara əsaslanaraq demək olar ki, zədələnmənin lateralizasiyası beyin qan dövranının kəskin pozulması olan xəstələrdə klinik və immunoloji parametrləri təyin edir. Bu zaman beyin qan dövranının pozulmasının patogenezində müəyyən rol oynayan faktorlarla immun mexanizmlər arasında six əlaqə qeyd edilir. Qeyd etmək lazımdır ki, erkən yaşlı uşaqlarda immunpatoloji fenomenlərin gələcək detallı öyrənilməsi beyin qan dövranının kəskin pozulmalarının diaqnostikası və patogenetik əsaslanmış farmakoterapiyasının yeni imkanlarını aşkar etməyə yardımçı olacaq.

Açar sözlər: beyin qan dövranının kəskin pozulması, insult, immun mexanizmlər.

Redaksiyaya daxil olub: 18.02 .2014

Çapa tövsiyə olunub: 11.03.2014

Rəyçi: t.ü.f.d., dos. Z.M.Sadıxova 